\title{
Pengaruh Proses Alkalisasi terhadap Morfologi Serat Tandan Kosong Kelapa Sawit untuk Bahan Penguat Komposit Absorbsi Suara
}

\author{
Rachmadhani D. Pratama, Moh. Farid, dan Haniffudin Nurdiansah \\ Departemen Teknik Material dan Metalurgi, Fakultas Teknologi Industri, Institut Teknologi Sepuluh \\ Nopember (ITS) \\ e-mail:mofaredo@gmail.com
}

\begin{abstract}
Abstrak-Komposit berpenguat serat alam saat ini menjadi salah satu material yang sedang dikembangkan. Tujuan dari penelitian ini adalah menganalisis pengaruh proses alkalisasi terhadap morfologi serat tandan kosong kelapa sawit. Penelitian ini menggunakan serat dari tandan kosong kelapa sawit yang berasal dari Dumai, Riau yang berukuran 140 - 224 $\mu \mathrm{m}$. Proses alkalisasi dilakukan dengan cara pengadukan dalam larutan $\mathrm{NaOH} 2 \%$ selama 3 jam menggunakan magnetic stirrer. Pengujian yang dilakukan dalam penelitian ini yaitu pengujian Scanning Electron Microscope (SEM). Dari hasil pengujian SEM didapatkan hasil bahwa proses alkalisasi menyebabkan permukaan serat menjadi kasar dan memiliki ukuran diameter sekitar 107-129 $\mu \mathrm{m}$.
\end{abstract}

Kata Kunci-Alkalisasi, NaOH, Serat Alam, Tandan Kosong Kelapa Sawit

\section{PENDAHULUAN}

$\mathrm{S}$ AAT ini perkembangan komposit dengan bahan dasar alam menjadi semakin pesat. Kebutuhan akan produk ramah lingkungan juga semakin tinggi. Oleh karena itu saat ini banyak material yang menggunakan serat dari tumbuhan yang digunakan sebagai penguat pada komposit bermatriks polimer. Pada perkembangannya, saat ini telah dikembangkan berbagai material komposit dari serat alam yang digunakan sebagai material peredam suara. Komposit serat alami merupakan salah satu alternatif bahan absorber suara. Serat alam pada umumnya memiliki kemampuan menyerap suara khususnya dalam mengendalikan kebisingan.

Kebisingan sendiri merupakan polusi suara yang berdampak negatif terlebih disektor transportasi. Kendaraan bermotor berpartisipasi sebanyak 55\% dalam kebisingan yang terjadi. Menurut PerMenLH No.07 Tahun 2009 tentang ambang batas kebisingan kendaraan bermotor tipe baru menyatakan bahwa kendaraan bermotor memiliki ambang batas kebisingan rata-rata $80 \mathrm{~dB}$ [1]

Penggunaan serat alam sebagai penguat pada komposit khususnya untuk material penyerap suara telah banyak diteliti sebelumnya [2], [3]. Salah satu serat alami yang sedang banyak dikembangkan saat ini adalah serat dari tandan kosong kelapa sawit. Indonesia dan Malaysia merupakan penghasil kelapa sawit terbesar di dunia. Akan tetapi, dalam produksi minyak kelapa sawit menghasilkan limbah yaitu berupa tandan kosong sebesar 1.1 ton pada setiap 1 ton minyak yang terproduksi [4].

Di Indonesia, tandan kosong kelapa sawit dimanfaatkan sebagai bahan pulp kertas, papan serat dan pengisi volume bahan furniture. Tandan kosong kelapa sawit yang dimanfaatkan memiliki berbagai karakteristik yang perlu dilakukan penelitian oleh karena itu diperlukan adanya penelitian yang mengkaji mengenai karakteristik serat tandan kosong kelapa sawit. Pengolahan serat tandan kosong kelapa sawit dimulai dari proses pengambilan sampel tandan kosong kelapa sawit, sampel tandan kosong kelapa sawit kemudian ditimbang beratnya sebelum diberikan perlakuan perebusan dan pengukusan, tandan kosong kelapa sawit dicuci dengan air bersih agar kotorankotoran yang tidak diinginkan berkurang.

Serat tandan kosong kelapa sawit banyak digunakan sebagai penguat dalam komposit. Hal ini dikarenakan tandan kosong kelapa sawit memiliki sifat-sifat mekanik yang baik, yang mana memenuhi apabila digunakan sebagai bahan penguat komposit. Sifat fisik dan mekanik dari serat tandan kosong kelapa sawit ditunjukkan oleh Tabel 1.

Tabel 1.

Sifat Fisik-Mekanik dari Serat Kelapa Sawit [4]

\begin{tabular}{lc}
\hline \multicolumn{1}{c}{ Sifat } & Nilai \\
\hline Diameter $(\mu \mathrm{m})$ & $150-500$ \\
Microfibrillar angle $\left(^{\circ}\right)$ & 46 \\
Density $\left(\mathrm{g} / \mathrm{cm}^{3}\right)$ & $0.7-1.55$ \\
Tensile strength $(\mathrm{MPa})$ & $50-400$ \\
Young's Modulus $(\mathrm{GPa})$ & $0.57-9$ \\
$\begin{array}{l}\text { Elongation at break }(\%) \\
\text { Tensile strain }(\%)\end{array}$ fiber & length \\
$\begin{array}{l}\text { Light-weighted } \\
(\mathrm{mm})\end{array}$ & 13.71 \\
& \\
\hline \hline
\end{tabular}

Tabel 2 .

Komposisi Kimia dari Serat Kelapa Sawit [5]

\begin{tabular}{lc}
\hline \multicolumn{1}{c}{ Property } & Range \\
\hline Cellulose (\%) & $42.7-65$ \\
Lignin (\%) & $13.2-25.31$ \\
Hemicellulosa (\%) & $17.1-33.5$ \\
Holocellulose (\%) & $68.3-86.3$ \\
Ash content $(\%)$ & $1.3-6.04$ \\
Extractives in hot water $(\%)$ & $2.8-14.79$ \\
Solubles in cold water $\left(30^{\circ} \mathrm{C}\right)(\%)$ & $8-11.46$ \\
& \\
Alkali soluble $(\%)$ & $14.5-31.17$ \\
Alfa-cellulose $(\%)$ & $41.9-60.6$ \\
\hline \hline
\end{tabular}

Dari Tabel 1, terlihat bahwa serat tandan kosong kelapa sawit memiliki diameter sekitar $150-500 \mu \mathrm{m}$. Diameter serat tandan kosong kelapa sawit masih cukup besar karena serat masih terdiri dari beberapa kandungan termasuk pengotor - pengotor. Nilai densitas dari serat tandan kosong kelapa sawit cukup rendah, sehingga baik untuk digunakan sebagai bahan dalam pembuatan komposit absorbsi suara. 


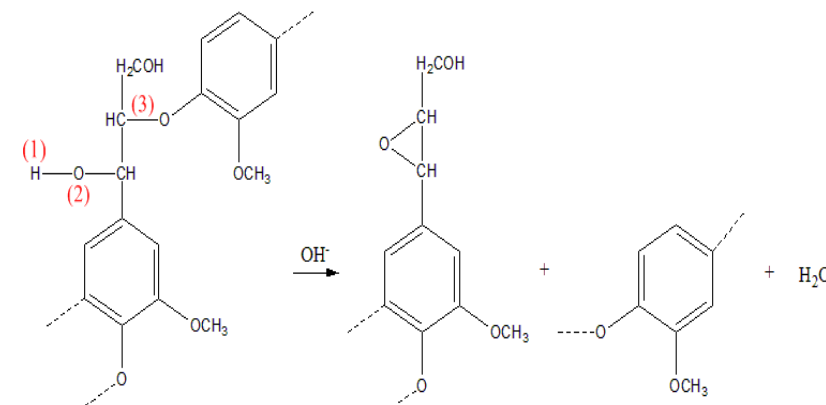

Gambar 1. Reaksi pada Proses Alkalisasi

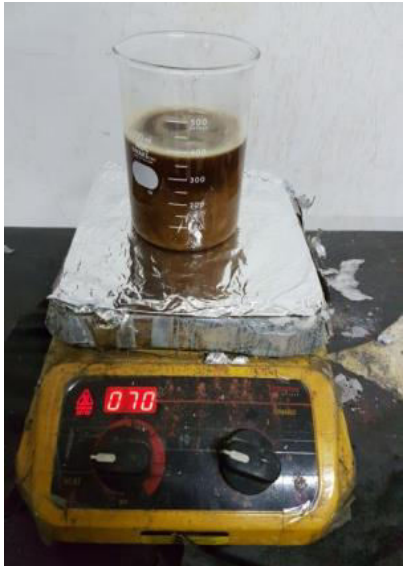

Gambar 2. Proses Alkalisasi Serat Tandan Kosong Kelapa Sawit

Tabel 1 juga menunjukkan beberapa sifat mekanik dari serat tandan kosong kelapa sawit yang cukup baik. Dari sifat - sifat fisik dan mekanik serat tandan kosong kelapa sawit tersebut, maka serat tandan kosong kelapa sawit cocok digunakan sebagai penguat komposit.

Selain sifat fisik dan mekanik, serat tandan kosong kelapa sawit memiliki komposisi kimia yang cukup baik. Serat dari tandan kosong kelapa sawit memiliki dua kandungan utama yaitu selulosa dan lignin. Komposisi kimia serat tandan kosong kelapa sawit ditunjukkan pada Tabel 2.

Dari Tabel 2 terlihat bahwa komposisi selulosa yang cukup banyak, dan juga komposisi lignin yang sedikit, maka serat tandan kosong kelapa sawit layak dan efisien untuk digunakan. Karena nanofibres selulosa yang berasal dari tanaman berpotensi untuk diekstraksi ke dalam serat yang lebih tipis dari selulosa bakteri, banyak peneliti telah secara ekstensif mempelajari ekstraksi selulosa dari serat serat alam. Di dinding sel, selulosa tertanam dalam zat matriks seperti hemiselulosa dan lignin, dan sampai saat ini, penghapusan zat matriks telah dilakukan sebelum proses fibrilasi. Selulosa memiliki peran dalam memberi kekuatan pada serat itu sendiri [6], dan juga tidak mudah terdegradasi secara kimia maupun mekanis. Selain itu, selulosa juga merupakan bahan yang dapat digunakan untuk aplikasi insulasi termal dan penyerapan suara [7]. Keuntungan utama dari penggunaan selulosa sebagai bahan penguat pada matriks polimer yaitu: densitas rendah, tidak mudah terabrasi, kemampuan mengisi tinggi yang menghasilkan sifat kekakuan yang tinggi, mudah didaur ulang, bahannya mudah didapat karena banyak tersedia di alam, dan murah. Akan tetapi serat tandan kosong kelapa sawit dan serat alam lainnya memiliki kekurangan apabila dijadikan penguat dalam komposit. Serat alami bersifat hidofilik sehingga menyebabkan gaya adhesi antara serat dan matriks bernilai rendah [8].

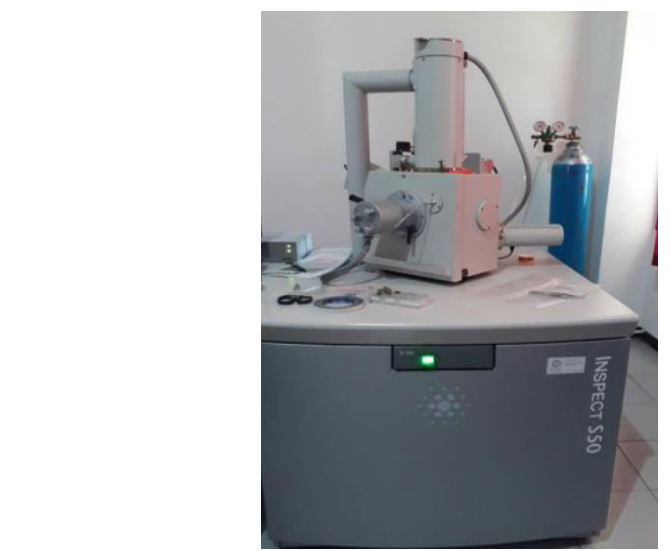

Gambar 3. SEM Inspect S50.

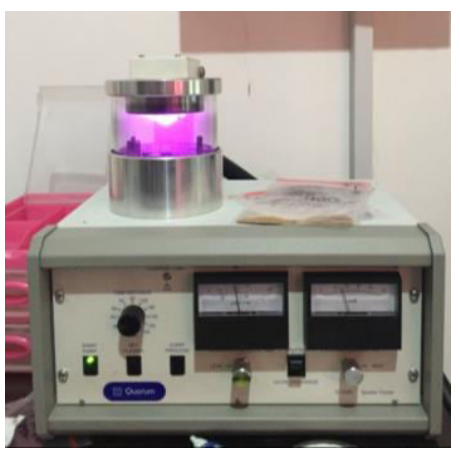

Gambar 4. Autofine-coater JFC-1100.

Maka dari itu, untuk mengoptimalkan sifat dari selulosa dan untuk menaikkan gaya adhesi antara serat dengan matriks polimer, dibutuhkan perlakuan baik perlakuan fisik maupun perlakuan kimia. Perlakuan kimia pada serat dapat mengubah struktur fisik maupun struktur kimia dari permukaan serat tersebut. Salah satu proses perlakuan kimia adalah alkalisasi. Alkalisasi merupakan metode yang paling banyak digunakan yang memiliki tujuan untuk menghilangkan kandungan lignin dan minyak yang menutupi permukaan luar seart. Efek yang timbul dari perlakuan alkalisasi adalah berubahnya ikatan hidrogen dalam struktur jaringan serat yang mengakibatkan permukaan serat menjadi kasar.

Pengaruh alkalisasi terhadap kinerja serat daun nanas/komposit PLA telah ditunjukkan [9]. Didapatkan bahwa perlakuan alkalisasi menyebabkan sifat mekanik komposit menjadi semakin unggul apabila dibandingkan dengan serat yang tanpa diberi perlakuan alkalisasi. Studi ini juga menunjukkan bahwa dengan proses alkalisasi dapat memodifikasi permukaan serat yang secara signifikan memberi kontribusi dalam memperbaiki sifat antarmuka dari biokomposit.

Perlakuan alkalisasi sendiri dilakukan dengan melakukan perendaman serat dalam larutan alkali basa yang biasanya berupa larutan $\mathrm{NaOH}$. Pada proses alkalisasi, lignin yang terdapat pada serat akan bereaksi dengan larutan basa $\mathrm{NaOH}$. Reaksi yang terjadi selama proses alkalisasi berlangsung ditunjukkan pada Gambar 1 .

Pada proses alkalisasi, lignin bereaksi dengan larutan $\mathrm{NaOH}$ yang terdisosiasi menjadi $\mathrm{Na}^{+}$dan $\mathrm{OH}^{-}$. Ion $\mathrm{OH}$ bereaksi dengan gugus $\mathrm{H}$ pada lignin, kemudian membentuk $\mathrm{H}_{2} \mathrm{O}$. Hal ini menyebabkan gugus $\mathrm{O}$ membentuk radikal bebas dan reaktif dengan $\mathrm{C}$ membentuk cincin epoksi (C-OC). Sehingga menyebabkan serangkaian gugus melepaskan ikatan pada gugus O. Reaksi menghasilkan dua cincin 
benzene yang terpisah, dimana masing-masing cincin memiliki gugus $\mathrm{O}$ yang reaktif. Gugus $\mathrm{O}$ reaktif ini bereaksi

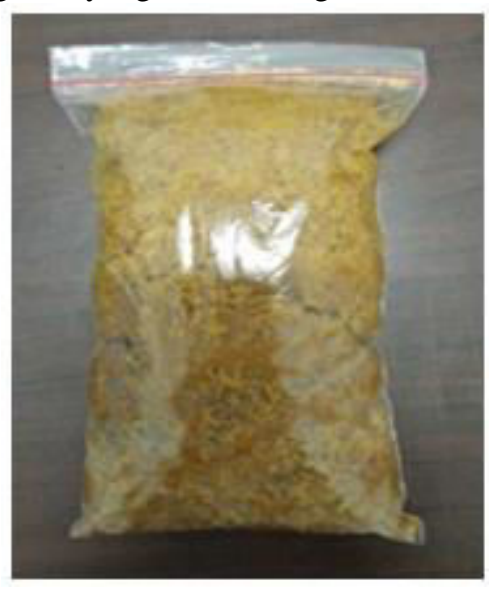

Gambar 5. Serat Hasil Proses Alkalisasi.

Oleh karena itu, untuk mengoptimalkan sifat dari selulosa, maka dilakukan proses alkalisasi dengan larutan $\mathrm{NaOH}$ yang bertujuan untuk menghilangkan lignin dan mengurangi diameter dari serat itu sendiri. Dan untuk mengetahui pengaruh proses alkalisasi terhadap perubahan morfologi pada serat dari tandan kosong kelapa sawit dianalisis dengan melakukan pengujian Scanning Electron Microscopy (SEM).

\section{METODE PENELITIAN}

\section{A. Bahan yang digunakan}

Bahan yang digunakan dalam penelitian ini adalah $\mathrm{NaOH}$ 2\% yang dibeli dari PT. Justus Kimiaraya Surabaya, aquades, serat Tandan Kosong Kelapa Sawit dari perkebunan kelapa sawit daerah Riau yang berukuran $140-$ $224 \mu \mathrm{m}$.

\section{B. Preparasi Serat Tandan Kosong Kelapa Sawit}

Serat kelapa sawit yang digunakan berasal dari daerah Dumai, Riau. Sebelum serat dialkalisasi, serat diperkecil ukurannya menggunakan blender dan di-sieving untuk menghomogenkan ukurannya menjadi 140-224 $\mu \mathrm{m}$.

Kemudian serat tandan kosong kelapa sawit yang berukuran $140-224 \mu \mathrm{m}$ diberi perlakuan kimia alkalisasi dalam larutan $\mathrm{NaOH} 2 \%$ pada $70^{\circ} \mathrm{C}$ selama 3 jam yang diproses menggunakan magnetic stirrer seperti ditunjukkan pada Gambar 2.

\section{Pengujian SEM}

Pengujian ini memiliki fungsi untuk mengetahui morfologi dari serat tandan kosong kelapa sawit. Pengujian dilakukan di Divisi Karakterisasi Material, Departemen Teknik Material dan Metalurgi Fakultas Teknologi Industri ITS dengan mesin SEM yang dipakai adalah SEM Inspect S50 yang ditunjukkan pada Gambar 3. Alat ini stabil pada arus penembakan yang tinggi (sampai dengan $2 \mu \mathrm{A}$ ) dengan tegangan $200-300 \mathrm{kV}$, perbesaran dari $13-1.000 .000 \mathrm{x}$, multi sample holder dengan hasil gambar yang akurat dan dapat mengkarakterisasi permukaan material dengan berbagai macam perlambatan cahaya untuk mendapatkan hasil yang tajam dan akurat.

Standar yang digunakan dalam pengujian SEM ini adalah ASTM E986 [11]. Langkah pengujian SEM yaitu spesimen dilapisi dengan AuPd terlebih dahulu dengan $\mathrm{Na}^{+}$dan ikut larut dalam larutan basa sehingga lignin hilang apabila dibilas [10].

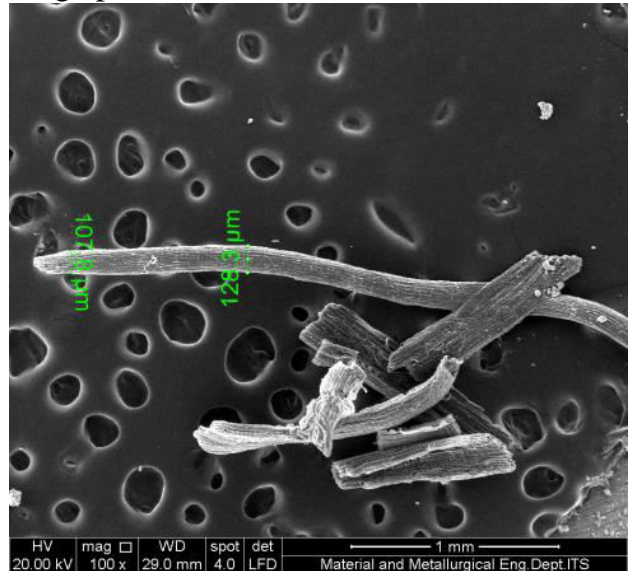

Gambar 6. Morfologi Serat Tandan Kosong Kelapa Sawit dengan Proses Perlakuan Alkalisasi.

menggunakan alat pelapis autofine-coater JFC-1100 yang ditunjukkan pada Gambar 4, agar serat yang awalnya tidak bersifat konduktor mampu menghantarkan elektron. Alat tersebut mampu meng-coating 20-30 nm dengan emas dengan waktu 2 menit dengan tekanan sampai dengan $4 \mathrm{~Pa}$. Chamber size $86 \mathrm{~mm} \times 100 \mathrm{~mm}$ dengan dinding kaca keras, dengan diameter spray 20-70mm dan temperatur kerja 15 $30^{\circ} \mathrm{C}$ dengan kelembaban sampai $70 \%$ [12].

Setelah dicoating, sampel dimasukkan dalam specimen chamber pada alat SEM. Perbesaran yang digunakan adalah antara 50-1000 kali. Cara kerja SEM adalah dengan menembakkan elektron dari electron gun lalu melewati condencing lenses dan pancaran elektron akan diperkuat dengan sebuah kumparan, setelah itu elektron akan difokuskan ke sampel oleh lensa objektif yang ada dibagian bawah. Pantulan elektron yang mengenai permukaan sampel akan ditangkap oleh backscattered electron detector dan secondary electron detector yang kemudian diterjemahkan dalam bentuk gambar pada display.

\section{HASIL DAN PEMBAHASAN}

\section{A. Hasil Pengamatan Visual}

Hasil proses perlakuan alkalisasi menggunakan larutan $\mathrm{NaOH} 2 \%$ selama 3 jam di temperatur $70^{\circ}$ ditunjukkan pada Gambar 5. Dari Gambar 5 terlihat bahwa serat tandan kosong kelapa sawit yang diberi perlakuan proses alkalisasi menjadi berwarna coklat. Perubahan juga ditunjukkan pada larutan basa, larutan $2 \% \mathrm{NaOH}$ yang awalnya berwarna putih berubah menjadi berwarna coklat setelah serat dimasukkan ke dalamnya. Perubahan warna larutan tersebut mengindikasikan bahwa pengotor - pengotor yang menempel pada serat tandan kosong kelapa sawit seperti lignin, dan ash ikut larut ke dalam larutan $\mathrm{NaOH} 2 \%$. Setelah serat dialkalisasi, serat dibilas menggunakan aquades untuk menghilangkan pengotor yang sudah larut dalam larutan $\mathrm{NaOH}$ tersebut.

\section{B. Hasil Pengujian SEM}

Serat tandan kosong kelapa sawit hasil alkalisasi kemudian di uji SEM untuk menganalisis morfologi dari serat. Gambar 6 menunjukkan morfologi serat tandan kosong kelapa sawit dengan perlakuan kimia alkalisasi. Hasil morfologi didapatkan dengan pengujian SEM dengan perbesaran 100x. 
Gambar 6 menunjukkan serat tandan kosong kelapa sawit yang dialkalisasi dengan $\mathrm{NaOH} 2 \%$ memiliki permukaan yang bersih tetapi terlihat adanya robekan apabila dilihat pada perbesaran 100x. Hal ini mengindikasikan bahwa pengotor - pengotor dalam serat telah hilang atau larut dalam larutan $\mathrm{NaOH} 2 \%$.

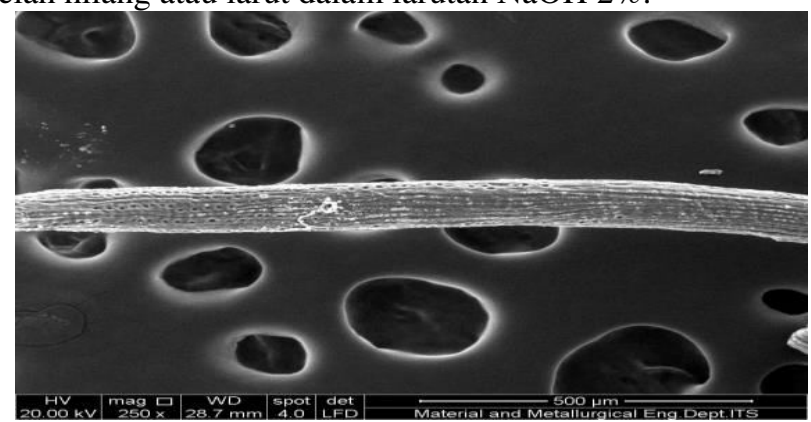

Gambar 7. Hasil SEM Permukaan Serat Tandan Kosong Kelapa Sawit Hasil Proses Alkalisasi Perbesaran 250x.

Pada proses alkalisasi, lapisan lilin (lignin) pada permukaan menghilang karena interaksinya dengan sodium [13]. Dengan hilangnya lapisan lilin dari serat akibat proses alkalisasi, dapat meningkatkan kontak area sehingga nantinya dapat meningkatkan sifat adhesi antara serat dengan matriks [14][15]. Dengan semakin baiknya ikatan antara serat tandan kosong kelapa sawit dengan matriks nantinya dapat membantu untuk memperbaiki sifat mekanik material. Serat tandan kosong kelapa sawit dengan proses alkalisasi memiliki diameter antara $107-129 \mu \mathrm{m}$. Pengurangan diameter serat tandan kosong kelapa sawit setelah dikenai proses alkalisasi terjadi karena ada beberapa kandungan dari serat yang ikut larut dalam $\mathrm{NaOH}$. Kandungan serat yang hilang antara lain lignin, ash, dan minyak yang melapisi bagian terluar serat. Saat bagian bagian tersebut hilang, maka ukuran diameter serat pun akan mengecil.

Hasil uji SEM permukaan serat tandan kosong kelapa sawit hasil proses alkalisasi juga ditunjukkan pada Gambar 7 dengan perbesaran 250x. Pada Gambar 7 menunjukkan di perbesaran 250x terlihat bahwa permukaan serat akibat adanya proses alkalisasi menjadi kasar, terdapat adanya lubang - lubang kecil pada permukaan serat.

Dari Gambar 6 dan 7 menunjukkan bahwa proses alkalisasi pada serat tandan kosong kelapa sawit mengakibatkan permukaan serat menjadi kasar, dan terdapat robekan dan juga lubang - lubang kecil. Kekasaran dari permukaan serat dapat membantu serat untuk memiliki gaya adhesi yang besar antara serat dengan matriks nantinya pada komposit.

Kekasaran pada permukaan serat tandan kosong kelapa sawit membuat gaya gesekan yang dapat menurunkan pergerakan yang mana dapat mengurangi aglomerasi serat itu sendiri. Hilangnya pengotor pada serat juga mengakibatkan daya penyerapan serat meningkat karena lubang pada permukaan serat itu sendiri [16].

\section{KESIMPULAN}

Perlakuan kimia yaitu proses alkalisasi dapat menyebabkan permukaan serat menjadi kasar dan terlihat adanya robekan. Selain itun ukuran serat menjadi sekitar $107-129 \mu \mathrm{m}$. Hal itu mengindikasikan bahwa dengan proses alkalisasi, pengotor - pengotor pada serat menghilang dengan cara larut bersama dengan larutan $\mathrm{NaOH} 2 \%$.

\section{UCAPAN TERIMA KASIH}

Penulis mengucapkan terima kasih kepada Program Penelitian Unggulan Perguruan Tinggi, Kemenristekdikti 2017 atas dukungan pendanaan dalam penelitian ini.

\section{DAFTAR PUSTAKA}

[1] M. Farid, H. Ardhyananta, V. M. Pratiwi, and S. P. Wulandari, "Correlation between Frequency and Sound Absorption Coefficient of Polymer Reinforced Natural Fibre," Adv. Mater. Res., vol. 1112, pp. 329-332, 2015.

M. Farid, "Correlation of Normal Incidence Sound Absorbtion Coefficient (NAC) and Random Incidence Sound Absorbtion Coefficient (RAC) of Polyester/Ramie Fibre Composite Materials," Adv. Mater. Res., vol. 789, pp. 269-273, 2013.

[3] M. Khalid, C. . Ratnam, T. G. Chuah, S. Ali, and T. S. Y. Choong, "Comparative study of polypropylene composites reinforced with oil palm empty fruit bunch fiber and oil palm derived cellulose," Mater. Des., vol. 29, pp. 173-178, 2008

[4] Shinoj, "Oil palm fiber (OPF) and its composites," Ind. Crops Prod., vol. 33, pp. 7-22, 2011.

[5] N. Saba and M. T. Paridah, "Dynamic Mechanical Properties of Oil Palm Nano Filler/Kenaf/Epoxy Hybrid Nanocomposite," Constr. Build. Mater., vol. 124, pp. 133-138, 2016.

[6] A. Wirajaya, "Karakteristik Komposit Sandwich Serat Alami Sebagai Absorber Suara," Bandung, 2007.

[7] P. Lertwattanaruk and A. Suntijitto, "Properties of Natural Fiber Cement Materials Containing Coconut Coir and Oil Palm Fibers for Residential Building Application," Constr. Build. Mater., vol 94, pp. 664-669, 2015.

[8] Faruk, Omar, Andrzej, K. Bledzki, H.-P. Fink, and M. Sain., "Biocomposites Reinforced with Natural Fibers," Prog. Polym. Sci., vol. 37, pp. 1552-1596, 2012.

[9] M. S. Huda, L. T. Drzal, A. K. Mohanty, and M. Misra, "Effect Of Chemical Modifications of the Pineapple Leaf Fiber Surfaces on the Interfacial and Mechanical Properties of Laminated Biocomposites," Compos. Interfaces, vol. 15, pp. 169-91, 2008.

[10] Sultoni, Yusuf, M. Farid, and A. T. Wibisono, "Pengaruh Proses Alkali dan Fraksi Massa Serat terhadap Sifat Fisik dan Sifat Mekanik Komposit Polyurethane/Coir Fiber," Surabaya, 2017.

[11] ASTM Standard E986, "Scanning Electron Microscpe Beam Size Characterization," 2004.

[12] Anonymous, "Inspect S50 Easy to use mainstream SEM enabling quick, accurate answers," 2014. [Online]. Available: http://www.fei.co.jp/_documents/DS0018-05-2014_Inspect_S50WEB.pdf.

[13] J. Rout, M. Misra, S. S. Tripathy, S. K. Nayak, and A.K Mohanty, "The Influence of Fibre Treatment on The Performance of Coir-Polyester Composites," Compos. Sci. Technol., vol. 61, pp. 1303-1310, 2001.

[14] M. A. N. Izani, M. T. Paridah, U. M. K. Anwar, M. Y. M. Nor, and P. S. H'ng., "Effects of Fiber Treatment on Morphology, tensile and Thermogravimetric Analysis of Oil Palm Empty Fruit Bunches Fibers," Compos. Part B, vol. 45, pp. 1251-1257, 2013.

[15] S. Mouhobi, M. E. H. Bourahli, H. Osmani, and S. Abdeslam, "Effect of Alkali Treatment on Alfa Fibers Behavior," J. Nat. Fibers, pp. 1-11, 2016.

[16] M. K. Bin Bakri, E. Jayamani, S. K. Heng, and S. Hamdan., "Reinforeced Oil Palm Fiber Fiber Epoxy Composites: An 
